\title{
Fatigue crack propagation in welded joints X70
}

\author{
Adel Deliou, Benattou Bouchouicha \\ Laboratory of Materials and Reactive Systems LMSR, University Djillali, Liabes, Sidi Bel-Abbes, Algeria. \\ del032003@yahoo.fr,benattou_b@yahoo.fr
}

\begin{abstract}
Structural failure assessment approaches take into account local parameters, specimen geometry, loading and material. In the case of welded joints, in addition to these parameters, consideration must be given to the effect of the heterogeneity of properties due to welding. The objective of our work is to study the fatigue crack propagation of welded joint in API X70 pipeline steel. This experimental study focused on welded joints in the different parts, base metal, weld metal and heat affected zone. The concepts of fracture mechanics are used to analyze the harmfulness of defects in welded joints and the main part of fatigue life falls on the crack propagation. The results obtained show that the fatigue crack propagation rate of cracks in the heat affected zone is delayed compared to the other zones.

The effect of the microstructure and the quality of submerged arc welding of the studied X70 steel are significant. Tensile tests, hardness and measurement of energetically parameters complemented this work.
\end{abstract}

KEYWORDS. X70; Mechanical behaviors; Fatigue crack propagation; Energy.

\section{INTRODUCTION}

W

elding is one of the important assembly methods for manufacturing in steel structures. In current industrial practice, welded joints are an integral section of these complex configurations [1]. In general, fatigue behavior of welded materials is complicated by large variation in nature and properties of materials, presence of geometric defects and many factors intrinsic (inclusions, lack of penetration, gas pore), etc. [2-8]. Many studies show that, from such defects, the stage of initiation of the fatigue crack can be reduced [9] and that consequently a large part of the life of the welded joints subjected to fatigue propagation occurs [10]. For the design of these assemblies, it is interesting to use the crack propagation laws given by the Linear Elastic Fracture Mechanics [LEFM]. In order to estimate the life of the joints, by calculating the number of cycles needed to propagate a crack from these defects until the rupture [11-21].

Welded structures present a gradient of microstructure and mechanical behaviors from the weld metal to base metal. Important studies regarding the microstructural change and the mechanical behaviors of API X70 steel have been executed [22- 24]. Nanninga [25] examined the fatigue crack propagation of API X42 and APIX70 pipelines at a load ratio $\mathrm{R}=0.1$ under $\mathrm{H}_{2}$ or $\mathrm{N}_{2}$ environment. The presence of hydrogen shows an important damage compared to Nitrogen. The 
fatigue crack propagation FCP tested under the same type of environment (Hydrogen or Nitrogen) is higher than the API 5L X70 steel because of the microstructure and the chemical composition.

The effect of toughness and microstructure on fatigue crack propagation rate in different steels X60 and X70 investigated by Y. Zhong et al. [26]. The results demonstrated that the toughness and strength have a significant influence to the fatigue behavior of pipeline steels. Maamache [27] inspected the influence of successive welding repairs on the microstructure and mechanical properties of the heat affected zone HAZ of an API 5LX70 steel. Microstructural analysis has shown that beyond the second repair, the HAZ microstructure undergoes a significant change in grain morphology and size that increases with the number of repairs. As a result, the yield strength and toughness of the repaired specimens were degraded. After the second repair, the properties of the welded joints do not meet the acceptability criteria defined by the standards applied by API.

Fatoba [28] studied the oligocyclic fatigue behavior of API 5L X65 pipeline steel at room temperature. The author has shown that the increase in the amplitude of total deformation has the effect of decreasing the life of fatigue oligocyclic, and the amplitude of stress increases with the amplitude of plastic deformation.

The investigation [29] showed that the cracking rate of X65 steel is influenced by the crack direction. The parameters of the propagation model have been determined admitting to the Paris law and show that the T-S direction has an excellent resistance to fatigue cracking with respect to the T-L direction (rolling direction). Kim [30] characterized the fatigue of the X65 steel in the three regions base metal, welded and heat affected zone, he noticed that the difference in the cracking rate decreases when the values of the stress intensity factor $\Delta \mathrm{K}$ increase.

The finite element analysis performed by Hadjoui [30] for the X60 and X70 steels for a load ratio R $=0.2$ shows that the X70 presents a better resistance to fatigue. Recently Maachou [31] analyzed the fatigue crack growth behavior under constant amplitude and variable amplitude loading using terms of energy parameters.

The main objective of this work is to study the fatigue crack growth rate of low-carbon micro alloyed steel X70 welded joints used in pipeline manufacturing. This experimental study focused on the welded joints in the three different parts, namely in the unaffected base metal, the heat affected zone and the weld metal.

\section{MECHANICAL PROPERTIES}

\section{Materials}

he studied material is a microalloyed steel, API 5L X70 grade, used in pipeline manufacturing. The pipe is spirally welded by Submerged Arc Welding SAW process.

\section{Chemical composition}

In order to evaluate if the chemical composition of our material conforms to the specification imposed by API 5L, an analysis by optical emission spectroscopy has been used. The chemical compositions of X70 pipeline steel and of SAW weld metal in weight percent are shown in the Tabs. 1 and 2 respectively.

\begin{tabular}{cccccccccccccccc}
\hline $\mathrm{C}$ & $\mathrm{Mn}$ & $\mathrm{Si}$ & $\mathrm{Cr}$ & $\mathrm{Ni}$ & $\mathrm{Mo}$ & $\mathrm{V}$ & $\mathrm{Al}$ & $\mathrm{Ti}$ & $\mathrm{Nb}$ & $\mathrm{Cu}$ & $\mathrm{P}$ & $\mathrm{Sn}$ & $\mathrm{S}$ \\
0.064 & 1.640 & 0.290 & 0.051 & 0.009 & 0.021 & 0.050 & 0.038 & 0.020 & 0.056 & 0.023 & 0.011 & 0.036 & 0.004 \\
\hline
\end{tabular}

Table 1: Chemical composition of X70 (base metal, BM; wt $\%$ ).

\begin{tabular}{ccccccccccccccc}
\hline $\mathrm{C}$ & $\mathrm{Mn}$ & $\mathrm{Si}$ & $\mathrm{Cr}$ & $\mathrm{Ni}$ & $\mathrm{Mo}$ & $\mathrm{V}$ & $\mathrm{Al}$ & $\mathrm{Ti}$ & $\mathrm{Nb}$ & $\mathrm{Cu}$ & $\mathrm{P}$ & $\mathrm{Sn}$ & $\mathrm{S}$ \\
0.070 & 1.610 & 0.250 & 0.035 & 0.030 & 0.133 & 0.060 & 0.017 & 0.017 & 0.040 & 0.046 & 0.014 & 0.003 & 0.004 \\
\hline
\end{tabular}

Table 2: Chemical composition of filler metal (weld metal, WM; wt $\%$ ).

The equivalent carbon contents of the base metal and that of weld metal calculated to the expression (1) below proposed by the international institute of welding [32] are respectively $0.36 \%$ and $0.39 \%$. 


$$
C_{e q}=C+\frac{M n}{6}+\frac{C r+M o+V}{5}+\frac{N i+C u}{15}
$$

\section{Tensile test}

In order to evaluate the load strain curve and mechanical properties of X70, flat specimens according to API requirements were used .The tensile tests were carried out in $600 \mathrm{KN}$ capacity, MFL UHP PRUFSYSTEME servo hydraulic testing machine, at room temperature with a low displacement $\mathrm{rate}(1 \mathrm{~mm} / \mathrm{min})$.

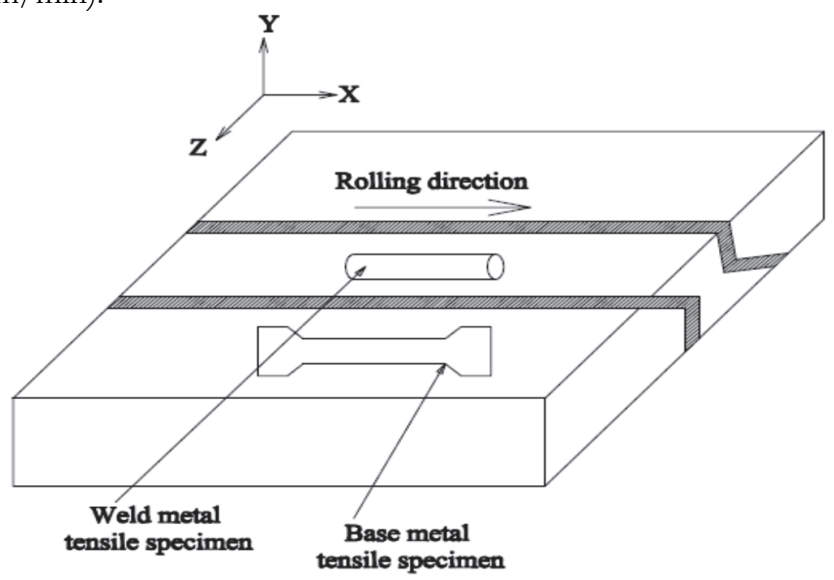

Figure 1: Schematic of the sampling direction of the specimens.

The samples were taken in the rolling direction (Fig.1). The dimensions of weld metal specimens used according to ASTM A370 and API 5L standard are presented in Fig. 2.

Tab. 3 and Fig. 3 present the results of conventional and true tensile of evolution of the stresses according to the deformation in base metal X70, where $\mathrm{E}$ the Young module, $\nu$ the Poisson's ratio, $\sigma_{Y}$ the yield strength, $\sigma_{U}$ ultimate strength, $\mathrm{A} \%$ the ductility and $\mathrm{k}$ and $\mathrm{n}$ being Hollomon's parameters. Tab. 4 shows the mechanical properties of the welded metal obtained.

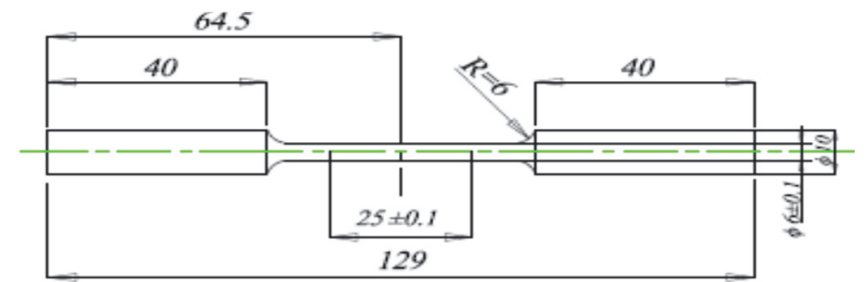

Figure 2: Diagram and dimensions of weld metal specimens used for tensile tests.

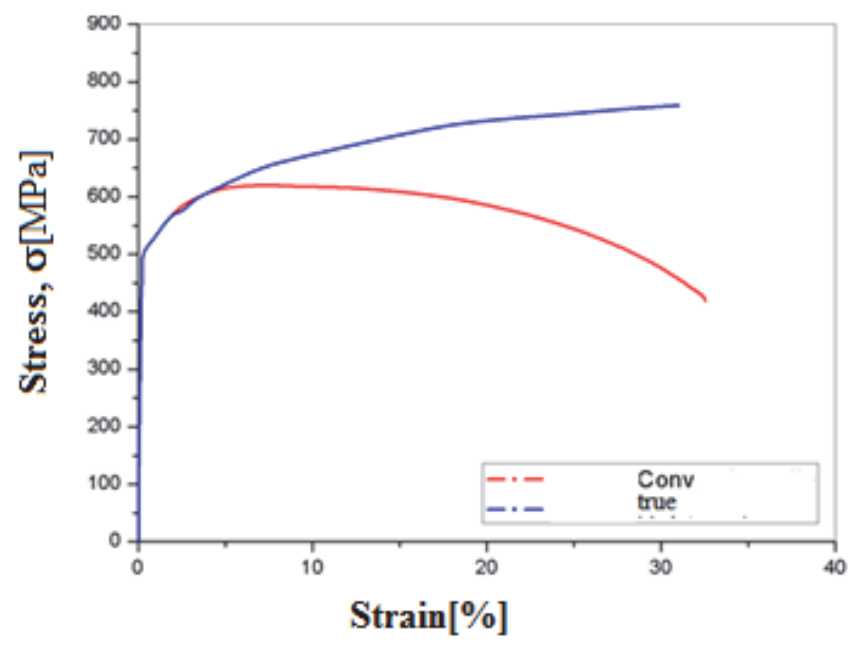

Figure 3: Conventional and true tensile curve of X70 


\begin{tabular}{ccccccc}
\hline $\mathrm{E}[\mathrm{GPa}]$ & $\nu$ & $\sigma_{\boldsymbol{Y}}[\mathrm{MPa}]$ & $\sigma_{\boldsymbol{U}}[\mathrm{MPa}]$ & $\mathrm{A}(\%)$ & $\mathrm{k}$ & $\mathrm{n}$ \\
221 & 0.3 & 500.3 & 573.14 & 33 & 840 & 0.25 \\
\hline
\end{tabular}

Table 3: Tensile properties of X70.

\begin{tabular}{cccc}
\hline Material & $\sigma_{\boldsymbol{Y}}[\mathrm{MPa}]$ & $\boldsymbol{\sigma}_{\boldsymbol{U}}[\mathrm{MPa}]$ & Elongation $(\mathrm{mm})$ \\
$\mathrm{WM}$ & 603.44 & 642.80 & 6.33 \\
\hline
\end{tabular}

Table 4: Tensile properties of weld metal

\section{Microstructure analysis}

In order to carry out the microstructural study of our material, we performed optical microscope observations on polished sections $(1 \mu \mathrm{m})$ then etched with 3\% Nital at the transverse surface of the welded joint (Fig. 4). Examinations performed on unaffected sections reveal the presence of numerous alignments of $\mathrm{MnS}$ inclusions in the base metal and globular oxides in the welded metal.

Optical micrograph shows an increase in grain diameter from the base metal to the weld joint. According to Fig. (5.a), the microstructure of the base metal consists as expected essentially of polygonal ferrite grains (white) and pearlite (black) organized in strips. This structure is produced by the segregation of $\mathrm{Mn}$ and $\mathrm{P}$ during rolling [34-37]. At the approach of the weld we find a more homogeneous organization of the grains The microstructure of the region near base metal consisted by equiaxed very fine grains of ferrite and pearlite.. For the heat affected zone (HAZ) (Fig. 5b), they appear acicular ferrite grains in the form of needles with coarse polygonal ferrite grains. The microstructure of the weld metal (WM) consists of dominant polygonal ferrite, acicular ferrite around the inclusions, and islands of pearlite (Fig.5c). The microstructure obtained is agreed with a number of studies oriented towards the analysis of the structure [26], [38-41].

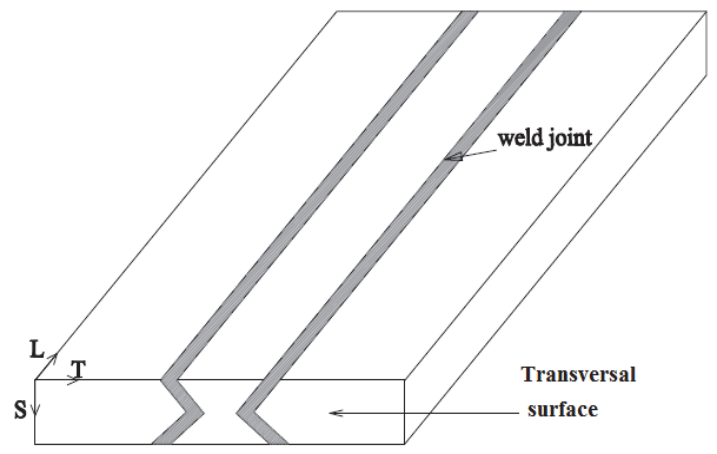

Figure 4: Transversal section for micrographic examinations and hardness measurement
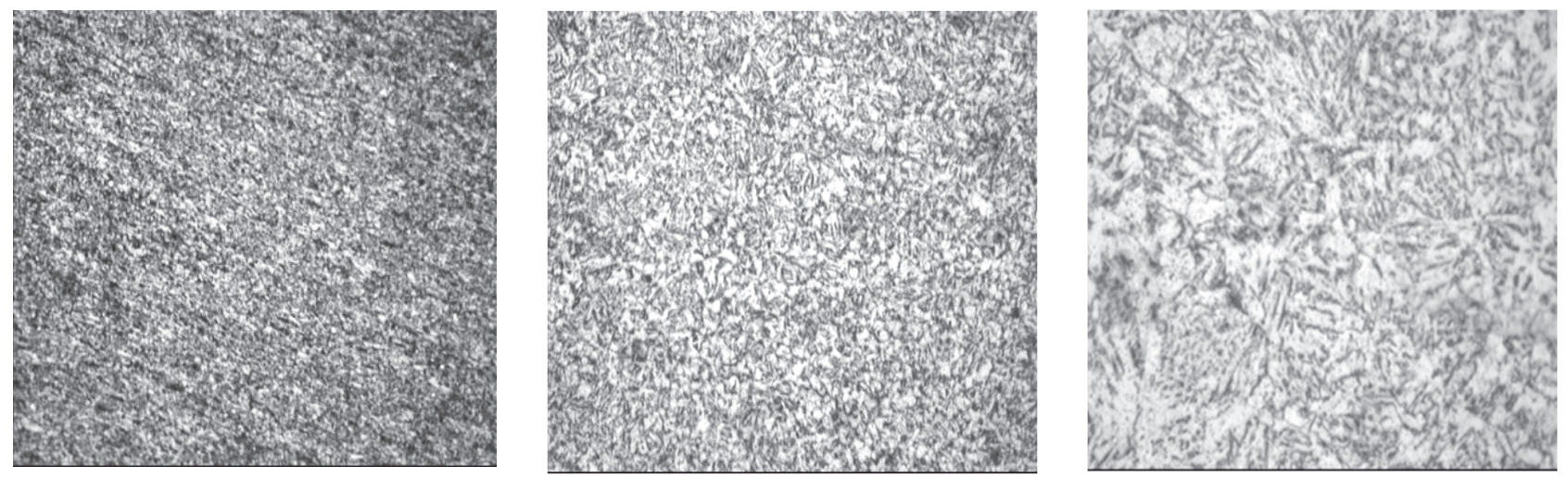

Figure 5: Welded joint microstructure as observed through optical microscopy: (a) base metal (M: X200) (b) heat affected zone (M: X200) and the weld metal (M: X500) (c) 


\section{Hardness measurement}

Vickers hardness filaments were carried out in the thickness on a cross section of the weld joint. The measurements are taken under $10 \mathrm{kgf}$ of load using a ZWICK ZHV10 type Durometer, the step is $0.5 \mathrm{~mm}$ in the HAZ and $1 \mathrm{~mm}$ in the base metal and the weld metal. The hardness profile measured across the average diameter changes to a letter $\mathrm{M}$ as shown in Fig. 6. In addition, Tab. 5 shows the average values of the Vickers hardness for each region of the welded joint. The large values of hardness of HAZ zone related to the existence of acicular ferrite in its microstructure (presents the greatest value of the mechanical properties by virtue of the fine-grained and interlocked microstructures) [42-44], on the other hand, the low values are in the BM respect to welded joint can be related by the reverse cold deformation caused by the rolling (Bauschinger effect). The hardness results representing the weld seam showed a uniformity of values between base metal and seam weld sign a good property.

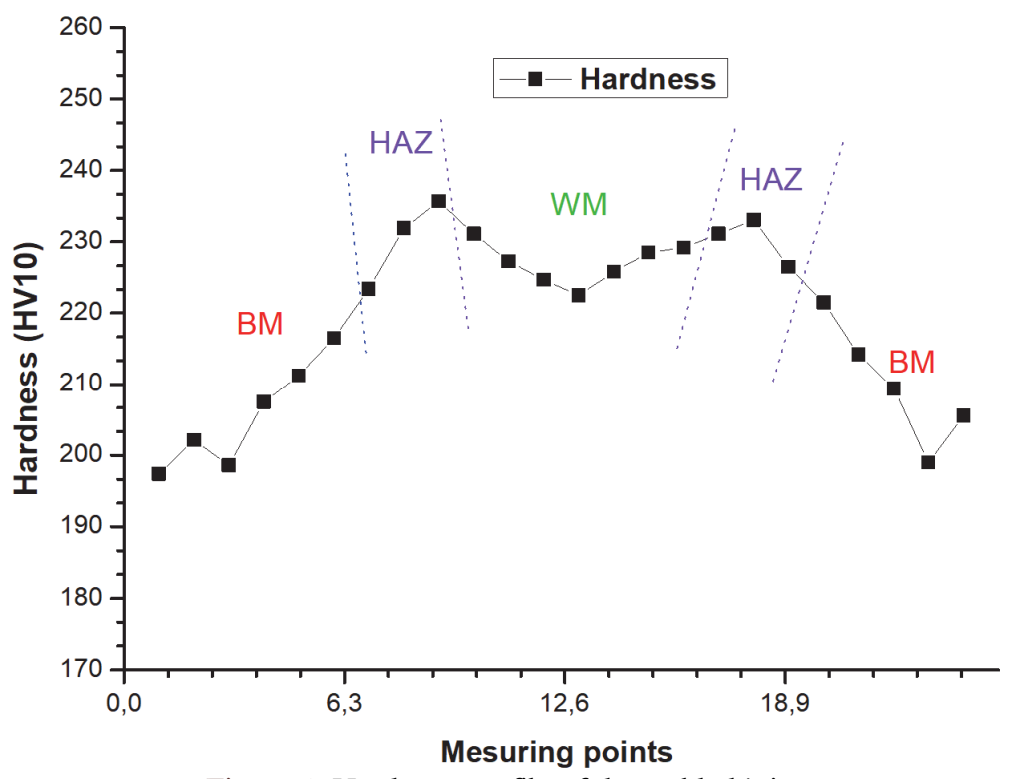

Figure 6: Hardness profile of the welded joint.

\begin{tabular}{cc}
\hline Region & Average value \\
BM & 207 \\
HAZ & 230 \\
WM & 227 \\
\hline
\end{tabular}

Table 5: Results of HV10 hardness along the weld joint

\section{FATIGUE TESTS}

$\mathrm{F}$ atigue cracking tests were performed on CT50 specimen's thickness of $7 \mathrm{~mm}$, in accordance with ASTME-E647 whose dimensions given by the Fig. 7. These tests were carried out in laboratory of materials and reactive systems (LMSR), Mechanical Department of University of Sidi Belabbes. These tests were conducted in ambient air for the same load ration value $\mathrm{R}$ at a nominal frequency of $20 \mathrm{~Hz}$ in the three zones.

Welded structures present a gradient of microstructure and mechanical behaviours from the weld metal to base metal. The study of fatigue crack growth in welded joints of pipeline steels, particularly in the heat affected zone, is difficult research field. In order to more clearly compare the evolution of the cracking rate in the three zones, we chose to represent them by their respective linear regression lines obtained from the experimental points (seven point method) on the linear parts of the curves. 

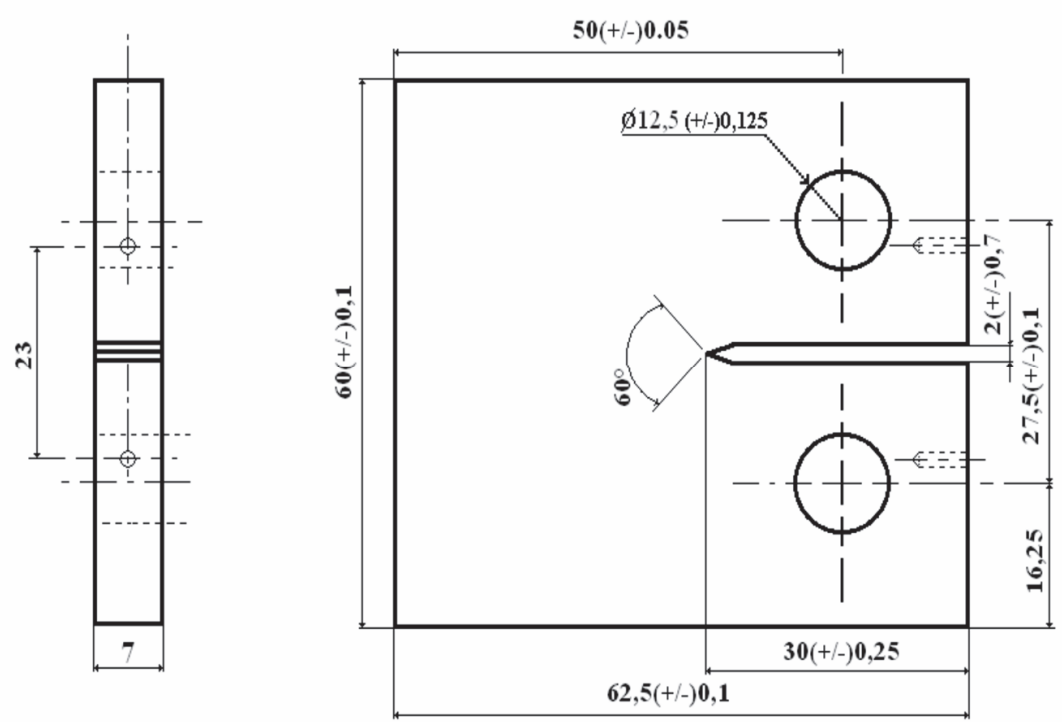

Figure 7: Diagram and dimensions of CT50 specimens used for cracking tests

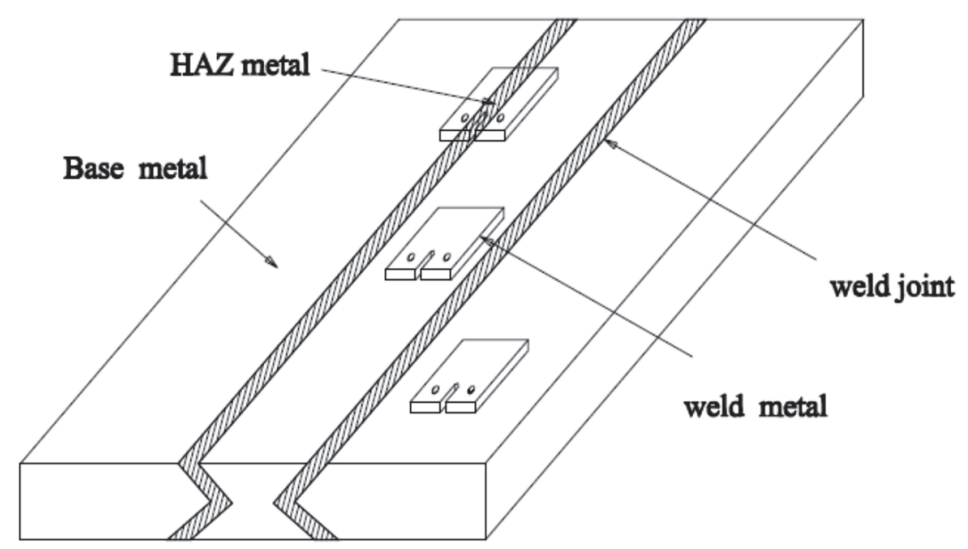

Figure 8: Orientation of the CT specimens with respect to the welded joints

According to the recommendations of ASTM E399 and AFNOR A03 404, the values of the stress intensity factor K in the case of CT geometry are calculated using the following relationship:

$$
K=\frac{P\left(2+\frac{a}{w}\right)}{B \sqrt{w}\left(1-\frac{a}{w}\right)^{\frac{3}{2}}} f\left(\frac{a}{w}\right)
$$

where $P$ the amplitude of loading $[\mathrm{N}]$, w is the width of specimen $[\mathrm{m}], \mathrm{B}$ is thickness of specimen $[\mathrm{m}]$ and a, is the crack length.

The compliance function $f\left(\frac{a}{w}\right)$ is on the form $[26,45]$ :

$$
f\left(\frac{a}{w}\right)=0.886+4.46\left(\frac{a}{w}\right)-13.31\left(\frac{a}{w}\right)^{2}+14.72\left(\frac{a}{w}\right)^{3}-5.6\left(\frac{a}{w}\right)^{4}
$$




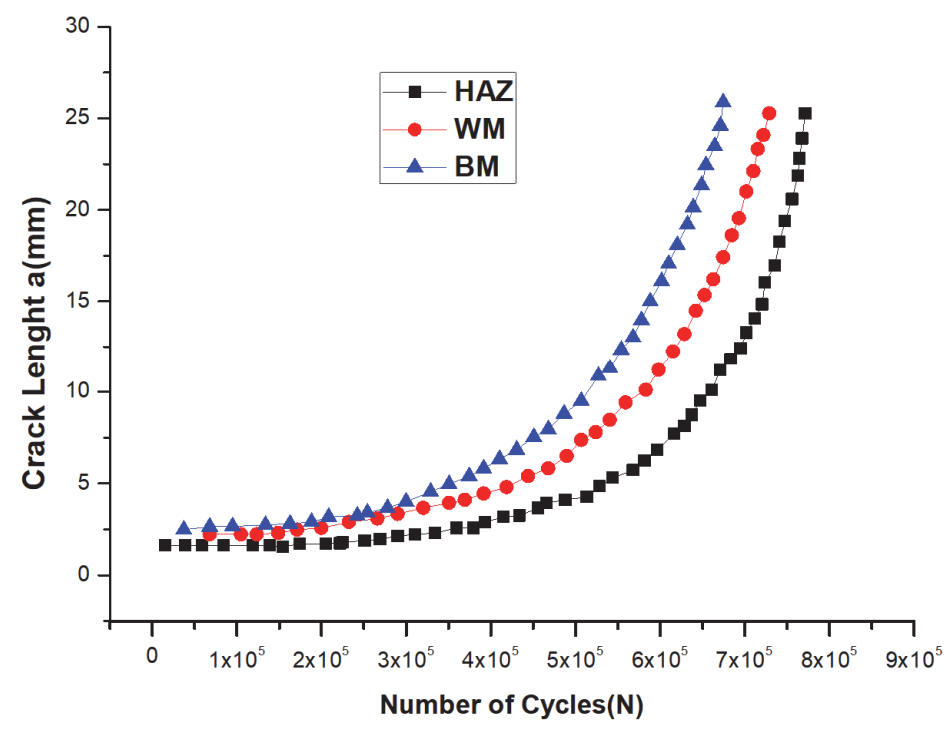

Figure 9: Evolution of the crack length according to the number of cycles.

In order to explore the field of medium and high cracking rates, we imposed a sinusoidal load of constant amplitude $\Delta P=7 \mathrm{KN}$ for the duration of the test, with a load ratio $\mathrm{R}=0.1$.

The curves of evolution of the length of the crack " $a$ " as a function of number of cycles of BM, WM and HAZ regions of welded joint are presented in Fig 9. The difference in advanced of the crack between these curves in higher as the number of cycles increases. These results influenced on the evolution of the nominal cracking rate versus plotted on a bilogarithmic curve shown in Fig. 10.

Values of $\frac{d a}{d N}$ are between $10^{-6}$ and $10^{-2} \mathrm{~mm} /$ cycle and the values of $\Delta K$ values change from:

- 13.8 to $36.9 \mathrm{MPa} \sqrt{m}$ in the heat affected zone.

- 13.2 to $36.6 \mathrm{MPa} \sqrt{m}$ in the weld metal.

- 11.7 to $35.4 \mathrm{MPa} \sqrt{m}$ in the base metal.

The curves have an almost rectilinear look on a big part of the explorer domain, which can be presented a law of Paris of the form [46]:

$$
\frac{d a}{d N}=C(\Delta K)^{m}
$$

The results of the fatigue tests obtained in the three zones recorded respectively in Tab. 6 .

\begin{tabular}{cc}
\hline Regions & Paris law \\
BM & $\frac{d a}{d N}=1.1 E^{-11}(\Delta K)^{4.87}$ \\
WM & $\frac{d a}{d N}=5.2 E^{-11}(\Delta K)^{4.55}$ \\
HAZ & $\frac{d a}{d N}=8.1 E^{-11}(\Delta K)^{3.82}$ \\
\hline
\end{tabular}

Table 6: Paris law in the different zones studied. 


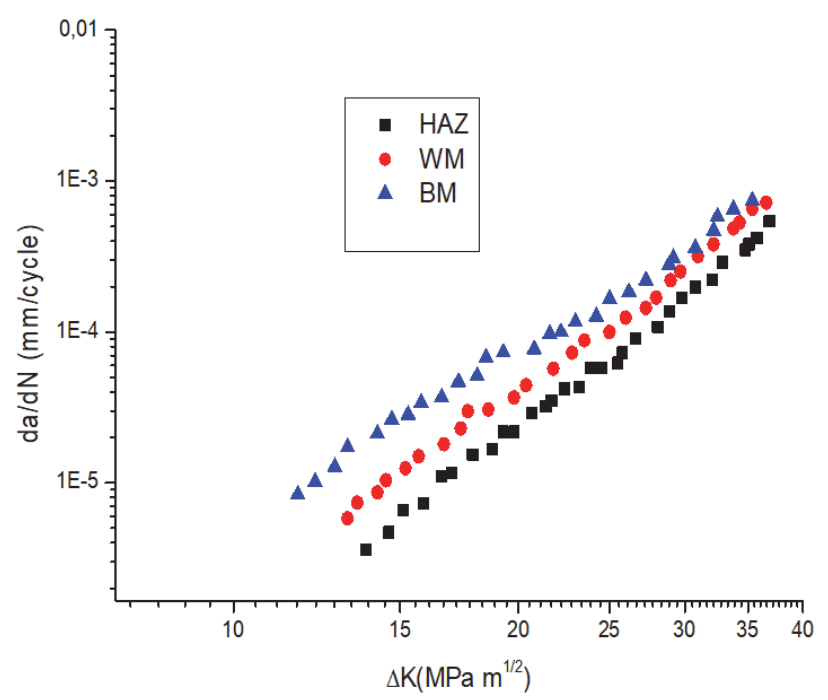

Figure10: Fatigue crack growth rates for as a function of $\Delta \mathrm{K}$ for the three zones studied

The results of Fig. 10 have shown that the welded metal and heat affected zone have an important higher crack propagation resistance at the small $\Delta \mathrm{K}$ values (The mechanical properties of weld material are better (Tabs. 3 and 4 ). The Paris equation coefficients obtained for the different X70 welded joint regions mentioned in Tab. 6 indicate that the growth rate of the crack influenced by the microstructure of the welded joint zones.

The high resistance to propagation of heat affected zone can be related to the existence of acicular ferrite in microstructure (Acicular ferrite microstructure in heat-affected zone give high mechanical behaviors in terms of strength and toughness) [47-49].

At the high values of $\Delta \mathrm{K}$, the affinity between cracking rate plots can be related for the decrease of crack closure. For low values of $\Delta K$ this phenomenon as more marked by the crack tip plasticity following its advance (thus forming a wake plasticized). These results are in good agreement with the results of Beltrao et al.[50] but, they noticed that the fatigue crack propagation is get more independent from the high load ratio values $(\mathrm{R}=0.5)$

\section{EVOLUTION OF ENERGY PARAMETERS}

$\mathrm{V}$ arious experimental techniques have been developed to measure the surface creation energy U. Most of these techniques are based on stable mechanical hysteresis loops, which measure work in an area near the crack.

Ikeda et al. [51] had measured the quantity for steel of low carbon content and for high resistance aluminium alloy from hysteresis loops in the plastic zone using strain micro gages. Using the differential method of Kikukawa et al. [52], Ranganathan measured the hysteric work $U$ [53], which represents the dissipated energy in the plastic zone by unit created surface on the aluminium alloy (2024 T351), testing CT specimens modified in order to be able to measure the crack tip opening displacement (CTOD) in the loading axial direction.

The progression of the crack tip opening displacement $\delta$, and $\delta$ ' with respect to the load $\mathrm{P}$ were registered at a frequency of $0.05 \mathrm{~Hz}$ ( $\delta$ evaluated by a clip gage). The differential displacement $\delta$ ' is calculated by the expression:

$$
\delta^{\prime}=\delta-\alpha \mathrm{P}
$$

$\alpha$ : The specimen compliance at a singular crack length.

The measurements were realized during one cycle for constant amplitude. Characteristic $\delta$ and $\delta$ ' with respect to the load $P$ layouts for constant amplitude loading are shown in Fig. 11.

(Crack opening load Pop was measured at the beginning of the horizontal segment on $\delta$ ' with respect to P diagram [54].

Fig. 12 shows the evolution of the hysteretic energy $Q$ dissipated during a cycle as a function of $\Delta \mathrm{K}$, for a load ratio $\mathrm{R}=$ 0.1 , in the three zones studied. This energy is determined by a numerical integration of the cycles $\left(P-\delta^{r}\right)$, its expression is obtained by calculating the area of this loop obtained by acquisition and processing by a program written under LABVIEW. 


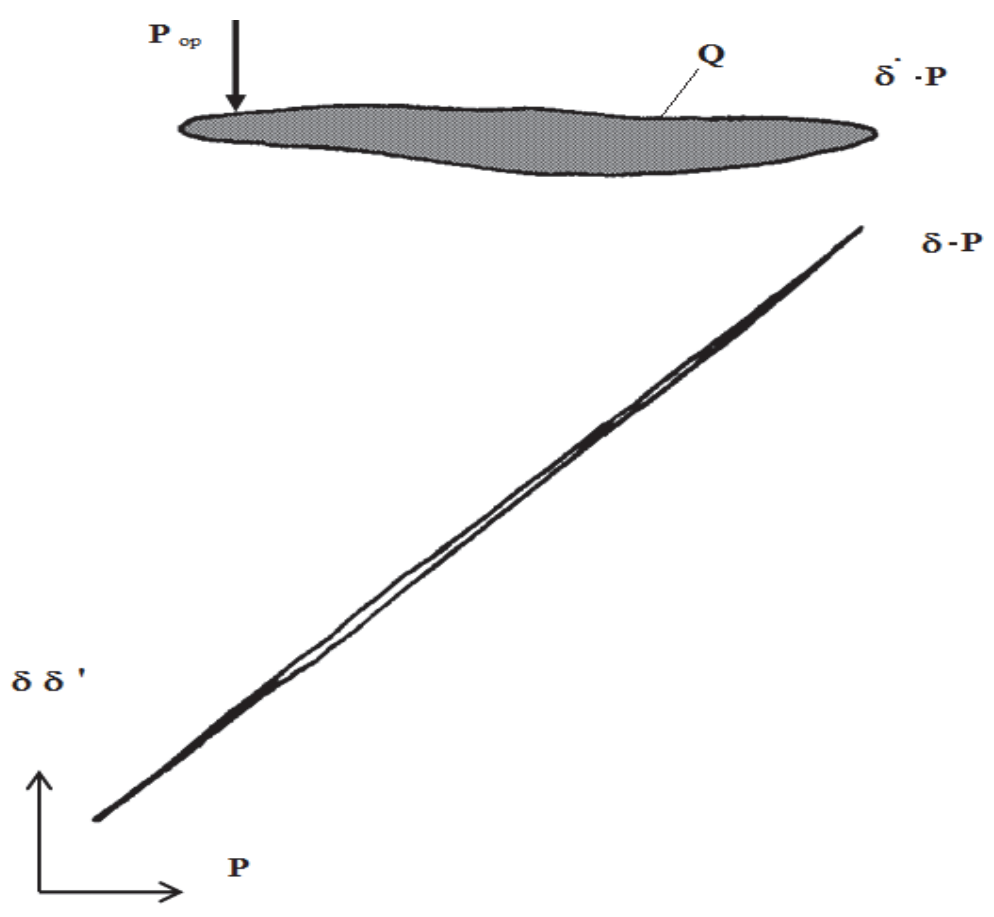

Figure 11: Diagrams of $\delta$ and $\delta$ 'with respect to charge P.

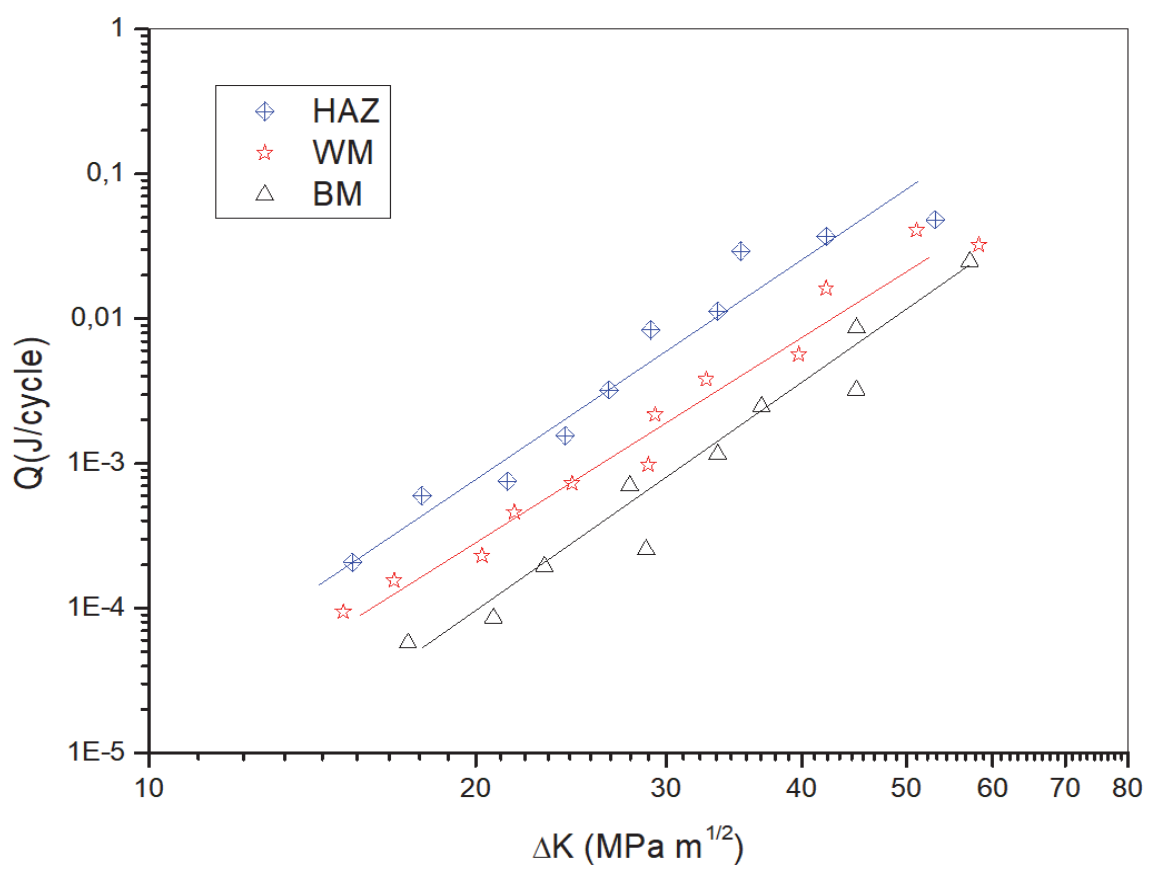

Figure12: Evolution of the hysterical energy of the crack as a function of $\Delta \mathrm{K}$

The advantage of this program is to be able to estimate this hysteretic energy for the low values of $\Delta \mathrm{K}$. We notice that $Q$ increases when $\Delta \mathrm{K}$ increases for the three zones studied.

Fig. 13 represents the evolution of the specific energy expended $U$ per cycle in function of $\Delta \mathrm{K}$ in the three zones studied. This energy is given by the following relation [31], [55]: 


$$
U=\frac{Q}{2 B\left(\frac{d a}{d N}\right)}=\frac{\left(\text { Area of the curve }\left(P-\delta^{\varsigma}\right)\right)}{2 B\left(\frac{d a}{d N}\right)}
$$

where $B$ the specimen thickness and $\frac{\mathrm{da}}{\mathrm{dN}}$ is the fatigue crack growth.

$U$ decreases with $\Delta \mathrm{K}$ at small $\Delta \mathrm{K}$ values to achieve a constant value at high $\Delta \mathrm{K}$ levels. These results indicated that the specific energy for the different zones of the weld joint studied is not a constant and depends the microstructure and on the decrease of crack closure phenomenon.

These results are consistent with the work of [53], [57-58] where they consider that the hysterical work is essentially dispelled in the plasticized zone and that in the case where the closing phenomena are important, it is conceivable that a part of the energy $U$ is dissipated in the zone situated in the wake plasticized along the crack front.

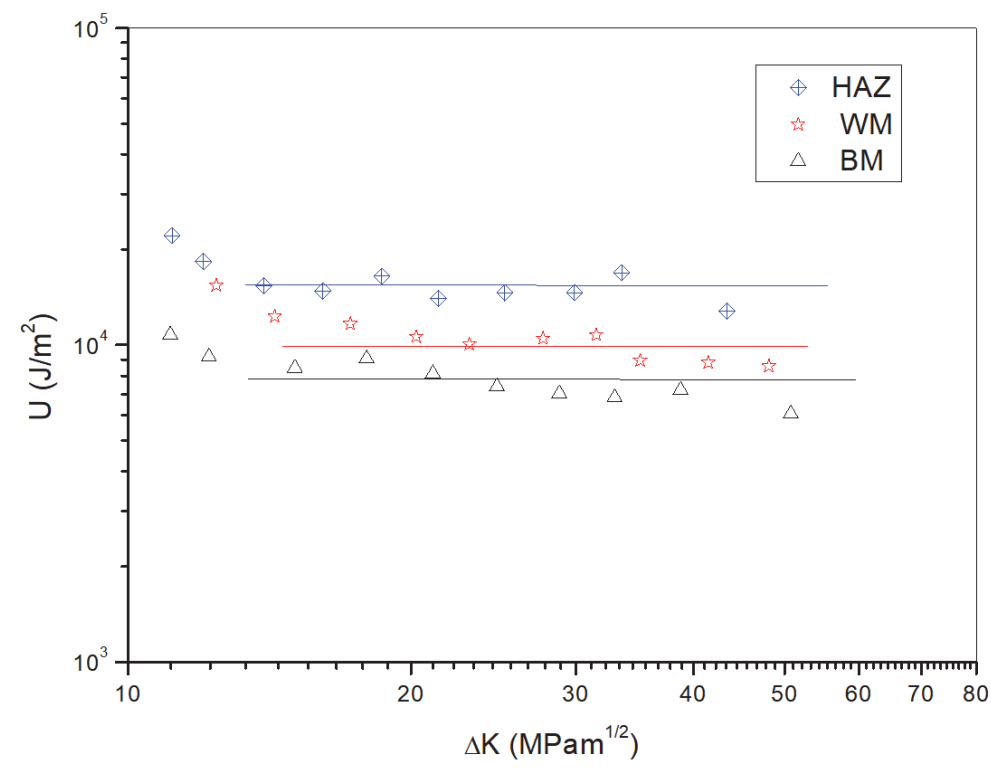

Figure 13: Evolution of specific energy as a function of $\Delta \mathrm{K}$

\section{CONCLUSION}

$\mathrm{F}$ atigue behavior of welded structures is a more complicated than that of base material due to the presence of heterogeneous metallurgical zones produced during the welding process.

Fatigue crack propagation in base metal BM, weld metal WM and heat affected zone HAZ of welded joints of an API X70 pipeline steel was investigated. The most generally model used for the fatigue crack growth based is LEFM and the crack propagation is the dominant stage of the fatigue life.

The fatigue crack growth behavior of welded joints API X70 pipeline steel affected by variation of microstructure, weld materials and the loading parameter.

Fatigue crack propagation in heat affected zone of X70 steel is delayed compared to the propagation to the other zones. The hysteretic energy $\mathrm{Q}$ dissipated during one cycle increases when $\Delta \mathrm{K}$ increases for the three zones studied and specific energy $\mathrm{U}$ reaches a constant value at high $\Delta \mathrm{K}$ levels.

\section{REFERENCES}

[1] Nykanen, T., Li, X., Bjork, T. and Marquis, G. (2005). A parametric fracture mechanics study of welded joints with toe cracks and lack of penetration, Engineering Fracture Mechanics, 72, pp.1580-1609. 
DOI: $10.1016 /$ j.engfracmech.2004.11.004.

[2] Ferreira, J. A. M. and Branco, C. A. M. (1989). Influence of the radius of curvature at the weld toe in the fatigue strength of fillet welded joints. Int. J. of fatigue, 11, pp. 29-36. DOI: 10.1016/0142-1123(89)90044-3.

[3] Janosh, J. J. (1990). Study of the fatigue strength of welded joints at angles (made of steel E 36-4), according to the size of the penetration of welds, in the case of a combined stress of traction and flexion., Ph.D. Dissertation, University of Metz, Metz.

[4] Otegui, J. L., H.W. Kerr, D. J. Burns, Mohaupt, U. H. (1998). Fatigue crack initiation from defects at weld toes in steel, Int. J. Pres .Ves. \&piping, 38, pp.385-417. DOI: 10.1016/0308-0161 (89)90048-3.

[5] Nguyen, N.T. (1990). Advanced modeling fatigue of butt-welded structures", Ph.D. Dissertation, University of Adelaide, Adelaide.

[6] Yee, R., Burns, D. J., Mohaupt, U. H., Bell, R. and Vosikovsky, O. (1990).Thickness effect and fatigue crack development in welded T joints, Journal of Offshore Mechanics and Arctic Engineering, 112, pp. $341-351$. DOI: $10.1115 / 1.2919876$.

[7] Kambouz, Y.M. Benguediab, B. Bouchouicha and Mazari, M. (2017). Numerical Study of the Mechanical Behavior and Fatigue in a Weld Bead by Friction Stir for a 6082-T6 Aluminum Alloy, Periodica Polytechnica Mechanical Engineering, 61(1), pp. 36-43. DOI: 10.3311/PPme.9212.

[8] Srivastava, Y. P. and Garg, S. B. L. (1985). Influence of R on effective stress range on effective stress range ratio and crack growth, Engineering Fracture Mechanics, 22(6), pp. 915-926. DOI: 10.1016/0013-7944 (85)90032-3.

[9] Benachour, M., M. Benguediab, Hadjoui, F. and Benachour, N. (2008). Fatigue crack growth of a double fillet weld, Computational Materials Science, 44, pp.489-495. DOI: 10.1016/j.commatsci.2008.04.015.

[10] Ngoula, D. T., H. T. Beier and Vormwald, M. (2017). Fatigue crack growth in cruciform welded joints: Influence of residual stresses and of the weld toe geometry, International Journal of Fatigue, 101(Part 2), pp.253-262. DOI: $10.1016 /$ j.ijfatigue.2016.09.020.

[11] Al-Haidary, J.T., Wahab, A.A. and. Abdul Salam, E.H. (2006). Fatigue Crack Propagation in Austenitic Stainless Steel Weldments, Metallurgical and Materials Transactions A, 37a, pp. 3206-3214. DOI: 10.1007/BF02586155.

[12] Bussu, G. and Irving, P.E. (2003). The role of residual stress and heat affected zone properties on fatigue crack propagation in friction stir welded 2024-T351aluminium joints, International Journal of Fatigue, 25, pp.77-88. DOI: $10.1016 / \mathrm{S} 0142-1123(02) 00038-5$.

[13] Chattopadhyay, A., Glinka, J., EL- Zine, G. M., Qian, J. and Formas, R. (2011). Stress analysis and fatigue of welded structures, welding in the world, 50(7\&8), pp. 1- 20. DOI: 10.1007/BF03321326.

[14] Chrysanthopoulos, M.K. and Righiniotis, T.D. (2006). Fatigue reliability of welded steel structures, Journal of Constructional Steel Research, 62, 2006, pp.1199-1209. DOI: 10.1016/j.jcsr.2006.06.007.

[15] Kainuma, S. and Mori, T. (2008). A study on fatigue crack initiation point of load-carrying fillet welded cruciform joints, International Journal of Fatigue, 30, pp.1669-1677. DOI: 10.1016/j.ijfatigue.2007.11.003.

[16] Mann, T., Tveiten, B. W. and Harkeegard, G. (2006). Fatigue crack growth analysis of welded Aluminium RHS Tjoints with manipulated residual stress level, Fatigue Fract Engng Mater Struct, 29, pp. 113-122. DOI: $10.1111 /$ j.1460-2695.2006.00970.x.

[17] Richards, C.E. and Lindley, T.C. (1972). The influence of stress intensity and microstructure in fatigue crack propagation in ferritic materials, Engineering Fracture Mechanics, 4, 1972, pp. 951-978. DOI: 10.1016/0013-7944(72)90028-8.

[18] Trudel, A., Sabourin, M., Levesque, M. and Brochu, M. (2014). Fatigue crack growth in the heat affected zone of a hydraulic turbine runner weld, International Journal of Fatigue, 66, pp.39-46. DOI: 10.1016/j.ijfatigue.2014.03.006.

[19] Tsay, L.W., Liu, Y.C, Young, M.C. and Lin, D. Y. (2004).Fatigue crack growth of AISI 304 stainless steel welds in air and hydrogen, Materials Science and Engineering A, 374, pp.204-210. DOI: 10.1007/BF02586155.

[20] Tveiten, B. W., Fjeldstad, A., Harkegard, G., Myhr, O. R. and Bjorneklett, B. ( 2006).Fatigue life enhancement of aluminium joints through mechanical and thermal prestressing, International Journal of Fatigue, 28, pp.1667-1676. DOI: $10.1016 /$ j.ijfatigue.2006.01.006.

[21] Ural, A., Krishnan, V. R. and Papoulia, K. D. (2009). A cohesive zone model for fatigue crack growth allowing for crack retardation, International Journal of Solids and Structures, 46, pp. 2453-2462. DOI: 10.1016/j.ijsolstr.2009.01.031.

[22] Bordbar, S., Alizadeh, M. and Hashemi, S. H. (2013). Effects of microstructure alteration on corrosion behavior of welded joint in API X70 pipeline steel, Materials and Design, 45, pp. 597-604. DOI: 10.1016/j.matdes.2012.09.051.

[23] Hwang, B., Kim, Y. G, Lee, S., Kim, Y. M., Kim, N. J. and Yoo, J. Y. (2005). Effective grain size and charpy impact properties of high-toughness X70 pipeline steels", Metallurgical and materials transactions A, 36A, pp. $2107-2114$. 
[24] Hejazi, D., Haq, A.J., Yazdipour, N., Dunne, D.P., Calka, A, Barbaro, F., Pereloma, E.V.(2012). Effect of manganese content and microstructure on the susceptibility of X70 pipeline steel to hydrogen cracking, Materials Science and Engineering A, 551, pp.40- 49. DOI: 10.1016/j.msea.2012.04.076.

[25] Nanninga, N., Slifka, A. Levy, Y. and White, C. (2010). A review of fatigue crack growth for pipeline steels exposed to hydrogen, Journal of research of the national institute of standards and technology, 115(6), pp.437-452. DOI: $10.6028 /$ jres.115.030.

[26] Zhong, Y., Shan, Y., Xiao, F. and Yang, K. (2005). Effect of toughness on low cycle fatigue behavior of pipeline steels, Materials Letters, 59, pp.1780- 1784. DOI: 10.1016/j.matlet.2005.01.066.

[27] Maamache, B., (2017). Structural and mechanical behavior of successive weld bead repairs in HSLA steel, Ph.D. Dissertation, University of Blida.

[28] Fatoba, O. and Akid, R. (2014). Low cycle fatigue behavior of API 5L X65 pipeline steel at room temperature, Procedia Engineering, 74, pp.279 - 286. Doi: 10.1016/j.proeng.2014.06.263.

[29] Neves, M. A. (2005). Fatigue crack propagation of longitudinal welded steel tubes, grade API 5L X70, Ph.D. Dissertation, University of Federal University of Rio de Janeiro.

[30] Kim, Y. P. Kim, C. M., Kim, W. S. and Shin, K. S. (2007). Fatigue Crack Growth Behavior in Girth Weld of Natural Gas Transmission Pipelines, Key Engineering Materials, 345-346, pp. 303-306. DOI: $10.4028 /$ www.scientific.net/KEM.345-346.303.

[31] Hadjoui, F., Benachour, M. and Benguediab, M. (2012). Fatigue Crack Growth on Double Butt Weld with Toe Crack of Pipelines Steel, Materials Sciences and Applications, 3, pp.596-599. DOI: 10.4236/msa.2012.39085.

[32] Maachou, S. Benguediab, M., Mazari, M. Ranganathan, N. (2014). Fatigue crack propagation under variable amplitude loading amplitude loading analyses based on plastic energy approach, Materials Engineering, 21, 2014, pp.68-79. Available online: http:/ / fstroj.uniza.sk/journal-mi/PDF/2014/11-2014.pdf

[33] Association de recherche sur les structures métalliques ARSEM -Guide pratique sur les ouvrages en mer, assemblage tubulaire soudé (1985), Edition TECHNIP, Paris.

[34] Carboni, A, Pigani, A., Paul, S. K. and Megahed, G.M. (2008). Casting and rolling of API X 70 grades for arctic applications in a thin slab rolling plant, Millennium steel, pp.131-136.

[35] Bulger, J. T., Lu, B. T. and Luo, J. L. (2006). Microstructural effect on near-neutral pH stress corrosion cracking resistance of pipeline steels, J Mater Sci., 41, pp. 5001-5005. DOI: 10.1007/s10853-006-0131-7

[36] Kumar, S. Shukla, S. K., De, S. K., Saxena, A., Jha, B. K, Mishra, B. Verma, A. and Mallik, S.( 2013). API X 70 Grade HR coils for ERW pipes, International Journal of Metallurgical Engineering, 2(2), pp.179-187. Doi:10.5923/j.ijmee.20130202.09.

[37] Feng, R., Li, S., Zhu, X. and Ao, Q. (2015). Microstructural characterization and formation mechanism of abnormal segregation band of hot rolled ferrite/pearlite steel", Journal of Alloys and Compounds, 646, pp.787-793. DOI: $10.1016 /$ j.jallcom.2015.05.128.

[38] Beltrao, M. A. N., Castrodeza, E. M., Filho, F. D.M. and Bastian, F. L. (2005).Fatigue behavior of API Grade 5L X65 and X-70 steels welded under variable amplitude loading, Proceedings of COBEM 2005 18th International Congress of Mechanical Engineering, ABCM November 6-11, Ouro Preto, Brazil.

[39] Tassadit, D, (2013). Study of the harmfulness of defects in pipelines under hydrogen environments), Ph.D. Dissertation, University of Tizi ouzou.

[40] Hashemi, S.H., Sedghi, S., Soleymani, V. and Mohammadyani, D. (2012).CTOA levels of welded joint in API X70 pipe steel, Engineering Fracture Mechanics, 82, pp. 46-59. DOI: 10.1016/j.engfracmech.2011.11.022.

[41] Omale, J.I., Ohaeri, E.G., Tiamiyu, A.A., Eskandari, M., Mostafijur, K.M. and Szpunar, J.A.(2017).Microstructure, texture evolution and mechanical properties of X70 pipeline steel after different thermomechanical treatments, Materials Science \& Engineering A, 703, pp. 477-485. DOI: 10.1016/j.msea.2017.07.086.

[42] Dowling, J. M., Corbett, J.M. and Kerr, H.W. (1986). Inclusion phases and the nucleation of the acicular ferrite in Submerged Arc Welding in High Strength Low Alloy Steel, Metallurgical transaction A, 17A, pp.1611-1623.

[43] Shin, S.Y., Hwang, B., Lee, S., Kim, N. J. and Ahn , S. S.( 2007).Correlation of microstructure and Charpy impact properties Correlation of microstructure and Charpy impact properties in API X70 and X80 line-pipe steels, Materials Science and Engineering A, 458, pp.281-289. DOI: 10.1016/j.msea.2006.12.097.

[44] Zhong, Y., Xiao, F., Zhang, J., Shan, Y., Wang, W. and Yang, K. (2006). In situ TEM study of the effect of M/A films at grain boundaries on crack propagation in an ultra-fine acicular ferrite pipeline steel, Acta Materialia, 54, pp.435-443. DOI: 10.1016/j.jallcom.2015.05.128.

[45] Zeghloul, A. and Petit J. (1989).Influence de l'environnement sur la propagation des fissures courtes et longues dans un alliage léger type 7075, Revue Phys. Appl., 24, pp.893-904. 
[46] Paris, P.C. and Erdogan, F. (1963). A critical analysis of crack propagation law, J Basic Eng. (ASME), 85, 1963, pp.528-533. Doi:10.1115/1.3656900.

[47] Wan, X.L., Wang, H.H., Cheng, L. and Wu, K.M. (2012). The formation mechanisms of interlocked microstructures in low-carbon high-strength steel weld metals, Materials Characterization, 67, pp.41-51. DOI: 10.1016/i.matchar.2012.02.007.

[48] Ricks, R.A., Howell, P. R. and Barritte, G.S. (1982).The nature of Acicular ferrite in HSLA steel weld metals, Journal of materials science, 17, pp.732-740. DOI: 10.1007/BF00540369.

[49] Sorrija, B.A. and Nascimento, M. P.D. (2015). Fatigue crack growth rate analysis in an API 5L X70 steel pipe, Rio pipeline conferences \& exposition.

[50] Beltrao, M. A. N., Castrodeza, E. M. and Bastian, F. L. (2010). Fatigue crack propagation in API 5L X-70 pipeline steel longitudinal welded joints under constant and variable amplitudes, Fatigue \& Fracture of Engineering Materials \& Structures, 34,pp.321-328. DOI: 10.1111/j.1460-2695.2010.01521.x.

[51] Ikeda, S., Izumi, Y. Fine, M.E. (1977). Plastic work during fatigue crack propagation in a high strength low alloy steel and in 7050 Al-Alloy, Engineering Fracture Mechanics, 9, pp.123-136.

[52] Kikukawa, M., Jono, M. and Hora, H. (1977). Fatigue crack propagation and closure behavior under plane strain condition, International Journal of Fracture, 13, pp. 699-701. DOI: 10.1007/BF00017303.

[53] Ranganathan, N., Chalon, F. and Meo, S. (2008).Some aspects of the energy based approach to fatigue crack propagation, International Journal of Fatigue, 30, pp. 1921-1929. DOI: 10.1016/j.ijfatigue.2008.01.010.

[54] Benguediab, M, Bouchouicha, B., Zemri, M., Mazari, M. (2012). Crack propagation under constant amplitude loading based on an energetic parameters and fractographic analysis, Materials Research, 15 (4), pp.544-548. DOI: 10.1590/S1516-14392012005000072.

[55] Mazari, M., Bouchouicha, B., Zemri, M., Benguediab, M, Ranganathan, N. (2008). Fatigue crack propagation analysis based on plastic energy approach, Comput Mater Sci, 41, pp.344-349. DOI: 10.1016/j.commatsci.2007.04.016.

[56] Ranganathan, N. (1985). Contribution to the development of an energy approach to the propagation of a fatigue crack, Ph.D. Dissertation, University of Poitiers.

[57] Bouchouicha, B. (2007). Contribution to the study of ductile tear and the propagation of fatigue cracks in welded joints, Ph.D. Dissertation, University of Sidi Bel Abbes. 